\title{
Article
}

Mycosphere

\section{Dothiorella magnoliae, a new species associated with dieback of Magnolia grandiflora from China}

\author{
You CJ ${ }^{1}$, Liu X ${ }^{1}$, Li LX' ${ }^{1}$, Tsui $\mathrm{CKM}^{2}$ and Tian $\mathrm{CM}^{1 *}$ \\ ${ }^{1}$ The Key Laboratory for Silviculture and Conservation of Ministry of Education, Beijing Forestry University, Beijing \\ 100083, China \\ ${ }^{2}$ Faculty of Medicine, University of British Columbia, Vancouver, Canada V6H $3 Z 6$
}

You CJ, Liu X, Li LX, Tsui CKM, Tian CM 2017 - Dothiorella magnoliae, a new species associated with dieback of Magnolia grandiflora from China. Mycosphere 8(2), 1031-1041, Doi 10.5943/mycosphere/8/2/6

\begin{abstract}
Dothiorella magnoliae sp. nov. was identified and isolated from Magnolia grandiflora from Sichuan Province in China. The new taxon is described and illustrated based on unique morphological characteristics and phylogenetic analysis of the internal transcribed spacer (ITS) rDNA, and partial sequences of the elongation factor 1- $\alpha($ tefl- $\alpha)$ gene. Morphologically, $D$. magnoliae produces conidia with conspicuous constriction at septum and it also differs from other described Dothiorella species in the dimensions of conidia. Molecular data reveal that D. magnoliae forms a sister clade to other species of Dothiorella, thus a new species is introduced here.
\end{abstract}

Key words - Dothiorella - Magnolia dieback - multigene phylogeny - taxonomy

\section{Introduction}

Dothiorella species, like other members of the family Botryosphaeriaceae, are known to be pathogens, endophytes, and saprobes on a wide range of mainly woody hosts (Phillips et al. 2008, 2013, Abdollahzadeh et al. 2014, Li et al. 2014, Pitt et al. 2015, Dissanayake et al. 2016a,b, Doilom et al. 2017). Dothiorella was resurrected by Phillips et al. (2005) based on the type species $D$. pyrenophora, which has brown, 1-sepatate conidia that turn brown while attached to their conidiogenous cells (Liu et al. 2012, Phillips et al. 2013, Pitt et al. 2013, 2015, Abdollahzadeh et al. 2014, Dissanayake et al. 2016a,b, Wijayawardene et al. 2016, Doilom et al. 2017).

Spencermartinsia, typified by Spencermartinsia viticola (A.J.L. Phillips \& J. Luque) A.J.L. Phillips, A. Alves \& Crous (Phillips et al. 2008), was delineated from Dothiorella based on the presence of an apiculus at either end of the 1-septate ascospores. The affinity of the two genera was supported by molecular phylogeny using ITS and tefl- $\alpha$ (Phillips et al. 2013), although the asexual morphs between Spencermartinsia and Dothiorella have little differences; the conidia of these two genera are brown and 1-septate while they are still attached to the conidiogenous cells. However, Spencermartinsia could not be resolved from Dothiorella, based on the phylogenetic analysis of sixgene regions (Slippers et al. 2013). Yang et al. (2017) demonstrated that species of Spencermartinsia clustered within Dothiorella, and the two genera were considered to be synonymous. Six described Spencermartinsia species were also transferred to Dothiorella by Yang et al. (2017).

During a 2015-2016 survey of forest pathogens causing canker or dieback disease in 
southwestern China, one new species of Dothiorella were collected from Magnolia grandiflora Linn. in Daofu, Sichuan. This species is characterized by 1-sepatate conidia that become brown prior to the release from the conidiogenous cells, with obvious constriction at septum and it differs from all the described species. The aim of this study was to describe the novel taxon using both morphological and molecular data. Also, its phylogenetic relationship to other known species of Dothiorella is inferred using combined ITS and tefl- $\alpha$ sequence data.

\section{Materials \& Methods}

\section{Fungal Isolates}

Two specimens were collected from branches or twigs of $M$. grandiflora with canker from southwestern China in June 2015. Single conidium isolate was prepared and transferred onto $1.8 \%$ potato dextrose agar (PDA) in a Petri-dish, and incubated at $25{ }^{\circ} \mathrm{C}$. The representative strains are maintained in the China Forestry Culture Collection Center (CFCC) and Beijing Forestry University (BJFU). Specimens are deposited in the Museum of the Beijing Forestry University (BJFC).

\section{Morphology and culture characteristics}

Fruiting bodies produced on infected plant tissues and cultural characteristics after inoculation were observed. Morphological characteristics of the fruiting bodies were recorded using a Nikon stereomicroscope (NI-U, Japan), including the size and shape of conidiophores and conidia. More than 20 pycnidia were sectioned and 50 conidia were selected randomly for measurement. The mean, standard deviation of the mean and $95 \%$ confidence interval for the lengths and widths of conidia per specimen were recorded, with extremes of length and width (minimum and maximum) given in parenthesis. Cultural characteristics of strains incubated on PDA in the dark at $25{ }^{\circ} \mathrm{C}$ were studied. The taxonomic information is deposited in MycoBank (MB 821470).

\section{DNA extraction, PCR amplification and sequencing}

Genomic DNA was extracted from 7 day-old colonies grown on PDA using the protocol of Cubero et al. (1999). The ITS region was amplified using primers ITS1 and ITS4 (White et al. 1990). The partial translation elongation factor 1-alpha (tefl- $\alpha$ ) gene region was amplified using primers EF1-728F and EF1-986R (Carbone \& Kohn 1999). DNA sequencing was performed using an ABI PRISM $^{\circledR}$ 3730XL DNA Analyzer with BigDye ${ }^{\circledR}$ Terminater Kit v.3.1 (Invitrogen) at the Shanghai Invitrogen Biological Technology Company Limited (Beijing, China). DNA sequences were deposited in GenBank (Table 1).

\section{Phylogenetic analysis}

The new sequences generated in this study, and the reference sequences of all Dothiorella extype isolates selected from recent studies were included in the phylogenetic analyses (Table 1). Two species Neofusicoccum luteum (CBS 110299, CBS 110497) were used as outgroup. These sequences were checked manually and aligned in MAFFT v.7 (Katoh \& Standley 2013). Phylogenetic analyses were performed on a combined dataset of ITS and TEF sequences by PAUP ver. 4.0b10 (Swofford et al. 2001) for maximum parsimony (MP), MrBayes v. 3.1.2 for Bayesian inference (BI) and PhyML v.7.2.8 for maximum likelihood (ML) (Ronquist \& Huelsenbeck 2003). MP analysis was performed by a heuristic search algorithm (1,000 random-addition sequences) with tree bisection and reconnection (TBR) branch swapping. Maxtrees were set to 5,000, branches of zero length were collapsed and all equally parsimonious trees were saved. Descriptive tree statistics (Tree Length [TL], Consistency Index [CI], Retention Index [RI] and Rescaled Consistency [RC] were calculated. ML analysis was also performed with a GTR site substitution model. A bootstrapping (BS) analysis (1,000 replicates) was calculated to assess the branch support (Hillis \& Bull 1993). Bayesian inference (BI) analysis was done by a Markov Chain Monte Carlo (MCMC) algorithm (Rannala \& Yang 1996). A nucleotide substitution model was estimated by MrModeltest v.2.3 2.3 (Nylander 2004). For the BI analysis, two MCMC chains were run from 
Table 1 Isolates of Dothiorella used for phylogenetic and taxonomic studies

\begin{tabular}{|c|c|c|c|c|c|c|}
\hline \multirow[t]{2}{*}{ Species } & \multirow[t]{2}{*}{ Culture no. ${ }^{1, *}$} & \multirow[t]{2}{*}{ Hosts } & \multirow[t]{2}{*}{ Locality } & \multirow[t]{2}{*}{ Collectors } & \multicolumn{2}{|c|}{ GenBank Accession No. } \\
\hline & & & & & ITS & TEF1- $\alpha$ \\
\hline Dothiorella americana & CBS128309 & Vitis vinifera & $\begin{array}{l}\text { Missouri,United } \\
\text { States } \\
\text { Missouri,United }\end{array}$ & K.Striegle \& G.M.Leavitt & HQ288218 & HQ288262 \\
\hline Dothiorella americana & CBS128310 & V. vinifera & States & K.Striegle \& G.M.Leavitt & HQ288219 & HQ288263 \\
\hline D.brevicollis & CMW36463 & Acacia karroo & Pretoria,South Africa & F.Jami \& M.Gryzenhout & JQ239403 & JQ239390 \\
\hline D.brevicollis & CMW36464 & A. karroo & $\begin{array}{l}\text { Pretoria,South Africa } \\
\text { Northern Cape, South }\end{array}$ & $\begin{array}{l}\text { F.Jami \& M.Gryzenhout } \\
\text { F.J.J.van der Walt \& G. J. }\end{array}$ & JQ239404 & JQ239391 \\
\hline D.capri-amissi & CMW25404 & A.erioloba & Africa & G.J.Marais & EU101324 & EU101369 \\
\hline D.casuarini & CMW4855 & Casuarina sp. & Canberra,Australia & M.J.Wingfield & DQ846773 & DQ875331 \\
\hline D.casuarini & CMW4857 & Casuarina sp. & Canberra,Australia & M.J.Wingfield & DQ846774 & DQ875333 \\
\hline D.dulcispinae & CMW36460 & A. karroo & Pretoria,South Africa & F.Jami \& M.Gryzenhout & JQ239400 & JQ239387 \\
\hline D.dulcispinae & CMW36461 & A. karroo & Pretoria,South Africa & F.Jami \& M.Gryzenhout & JQ239401 & JQ239388 \\
\hline D.dulcispinae & CMW36462 & A. karroo & Pretoria,South Africa & $\begin{array}{l}\text { F.Jami \& M.Gryzenhout } \\
\text { F.J.J.van der Walt \& }\end{array}$ & JQ239402 & JQ239389 \\
\hline D.dulcispinae & CBS121764 & Acacia mellifera & Rundu,Namibia & $\begin{array}{l}\text { J.Roux } \\
\text { F.J.J.van der Walt \& }\end{array}$ & EU101299 & EU101344 \\
\hline D.dulcispinae & CBS121765 & A. mellifera & Pretoria,South Africa & R.N.Heath & EU101300 & EU101345 \\
\hline D.iberica & CBS115041 & Quercus ilex & Aragon,Spain & J.Luque & AY573202 & AY573222 \\
\hline D.iberica & CBS113188 & Quercus suber & Andalucia,Spain & M.E.Sanchez & AY573198 & EU673278 \\
\hline D.iranica & CBS124722 & $\begin{array}{l}\text { Olea europaea } \\
\text { Lysiphyllum }\end{array}$ & $\begin{array}{l}\text { Golestan,Iran } \\
\text { Tunnel }\end{array}$ & A.Javadi & KC898231 & KC898214 \\
\hline D.longicollis & CMW26165 & cunninghamii & $\begin{array}{l}\text { Creek,Australia } \\
\text { Tunnel }\end{array}$ & T.I.Burgess & EU144053 & EU144068 \\
\hline D.longicollis & CMW26166 & L. cunninghamii & Creek,Australia & T.I.Burgess & EU144054 & EU144069 \\
\hline D.moneti & MUCC505 & Acacia rostellifera & Yalgorup,Australia & K.M.Taylor & EF591920 & EF591971 \\
\hline D.moneti & MUCC506 & A. rostellifera & Yalgorup,Australia & K.M.Taylor & EF591921 & EF591972 \\
\hline D.neclivorem & DAR80992 & Vitis vinifera & Pokolbin,Australia & $\begin{array}{l}\text { N.Wunderlich } \\
\text { F.J.J. van der Walt \& R.N. }\end{array}$ & KJ573643 & KJ573640 \\
\hline D.oblonga & CMW25407 & A.mellifera & Pretoria, South Africa & $\begin{array}{l}\text { Heath } \\
\text { F.J.J. van der Walt \& R.N. }\end{array}$ & EU101300 & EU101345 \\
\hline D.oblonga & CMW25408 & A.mellifera & Pretoria, South Africa & $\begin{array}{l}\text { Heath } \\
\text { J.Abdollahzadeh \& }\end{array}$ & EU101301 & EU101346 \\
\hline D.parva & CBS124720 & Corylus avellana & Ardabil,Iran & $\begin{array}{l}\text { A.Javadi } \\
\text { J.Abdollahzadeh \& }\end{array}$ & КC898234 & KC898217 \\
\hline
\end{tabular}


Table 1 continued Isolates of Dothiorella used for phylogenetic and taxonomic studies

\begin{tabular}{|c|c|c|c|c|c|c|}
\hline \multirow[t]{2}{*}{ Species } & \multirow[t]{2}{*}{ Culture no. ${ }^{1, *}$} & \multirow[t]{2}{*}{ Hosts } & \multirow[t]{2}{*}{ Locality } & \multirow[t]{2}{*}{ Collectors } & \multicolumn{2}{|c|}{ GenBank Accession No. } \\
\hline & & & & & ITS & TEF1- $\alpha$ \\
\hline D.pretoriensis & CMW36481 & A. karroo & Pretoria,South Africa & F.Jami \& M.Gryzenhout & JQ239406 & JQ239393 \\
\hline D.prunicola & CBS124723 & $\begin{array}{l}\text { Prunus dulcis } \\
\text { Santalum }\end{array}$ & Algarve,Portugal & E.Diogo & EU673313 & EU673280 \\
\hline D.santali & MUCC508 & acuminatum & Yalgorup,Australia & K.M. Taylor & EF591923 & EF591974 \\
\hline D.santali & MUCC509 & S. acuminatum & $\begin{array}{l}\text { Yalgorup,Australia } \\
\text { Warwickshire,Englan }\end{array}$ & K.M. Taylor & EF591924 & EF591975 \\
\hline D.sarmentorum & IMI63581b & Ulmus sp. & d & E.A. Ellis & AY573212 & AY573235 \\
\hline D.sempervirentis & CBS124718 & sempervirens & Golestan,Iran & M.A.Aghajani & KC898236 & KC898220 \\
\hline D.sempervirentis & CBS124719 & C. sempervirens & $\begin{array}{l}\text { Golestan,Iran } \\
\text { Kerikeri,New }\end{array}$ & M.A .Aghajani & KC898237 & KC898219 \\
\hline D.striata & CBS124730 & Citrus sinensis & $\begin{array}{l}\text { Zealand } \\
\text { Kerikeri,New }\end{array}$ & P.R.Johnston & EU673320 & EU673287 \\
\hline D.striata & CBS124731 & C. sinensis & Zealand & P.R.Johnston & EU673320 & EU673287 \\
\hline D.symphoricarposicola & MFULCC130497 & Symphoricarpos sp. & Forli-Cesena, Italy & Erio Camporesi & KJ742378 & KJ742381 \\
\hline D.thripsita & BRIP51876 & $\begin{array}{l}\text { harpophylla } \\
\text { Hexachlamis }\end{array}$ & Tallegalla,Australia & D.J.Tree \& C.E.C.Tree & KJ573642 & KJ573639 \\
\hline D.uruguayensis & CBS124908 & edulis & $\begin{array}{l}\text { Paysandu,Uruguay } \\
\text { Eden }\end{array}$ & C.A.Perez & EU080923 & EU863180 \\
\hline D.vidmatera & DAR78992 & Vitis vinifera & Valley,Australia & W.M. Pitt \& A. Loschiavo & EU768874 & EU768881 \\
\hline D.vidmatera & DAR78993 & $V$. vinifera & Loxton,Australia & W.M. Pitt \& A. Loschiavo & EU768876 & EU768882 \\
\hline D.vinea-gemmae & DAR81012 & $V$. vinifera & Pokolbin,Australia & N. Wunderlich & KJ573644 & KJ573641 \\
\hline Dothiorella sp.1 & CBS242.51 & Unknow & Italy & R, Ciferri & EU673317 & EU673284 \\
\hline Dothiorella sp.1 & CBS188.87 & Juglans regia & France & Meylan & CBS188.87 & EU673283 \\
\hline Dothiorella sp.1 & CBS 124716 & J. regia & Jolfa,Iran & J. Abdollahzadeh \& A.Javadi & КC898232 & KC898215 \\
\hline Dothiorella sp.1 & CBS124717 & J. regia & Kermanshah, Iran & J.Abdollahzadeh \& A.Javadi & KC898233 & KC898216 \\
\hline Dothiorella sp.1 & CMW25743 & Ostrya carpinifolia & $\begin{array}{l}\text { Lochere,Italy } \\
\text { Eden Valley, }\end{array}$ & G.Maresi & FM955386 & FM955418 \\
\hline Dothiorella sp.1 & DAR78991 & Vitis vinifera & $\begin{array}{l}\text { Australia } \\
\text { Kerikeri, }\end{array}$ & W.M. Pitt \& A. Loschiavo & EU768875 & EU768880 \\
\hline D.citricola & CBS124728 & Citrus sinensis & $\begin{array}{l}\text { Zealand } \\
\text { Kerikeri, }\end{array}$ & P.R. Johnston & EU673322 & EU673289 \\
\hline
\end{tabular}


Table 1 continued Isolates of Dothiorella used for phylogenetic and taxonomic studies

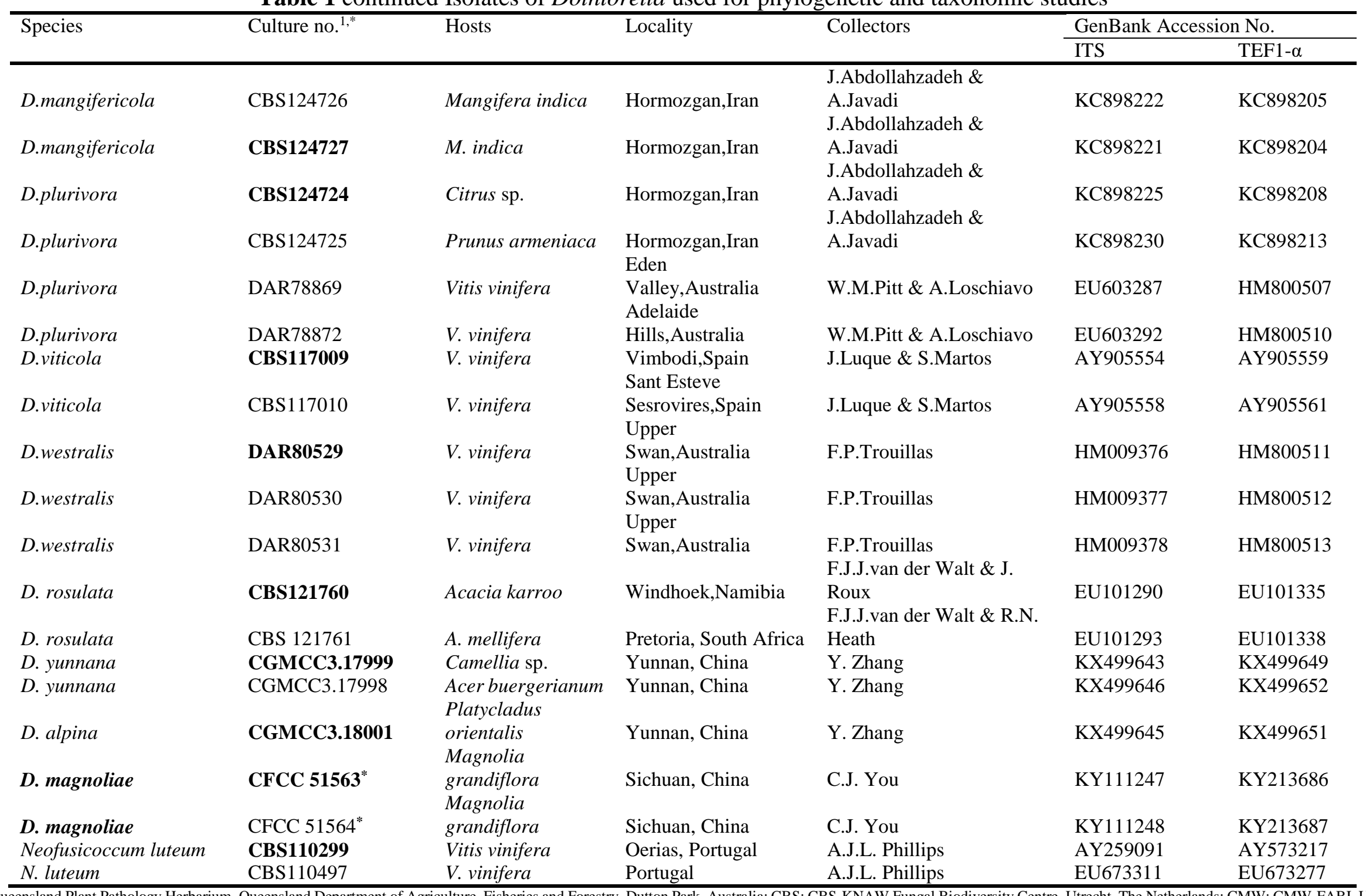

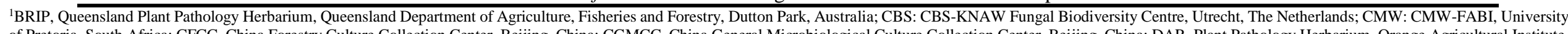

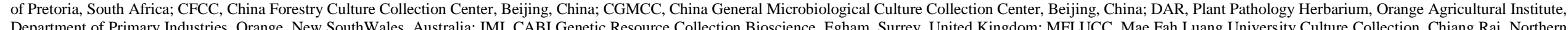

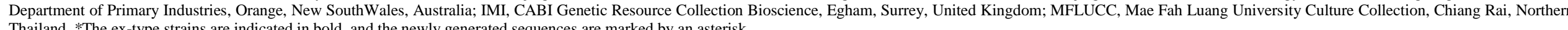
Thailand. *The ex-type strains are indicated in bold, and the newly generated sequences are marked by an asterisk 


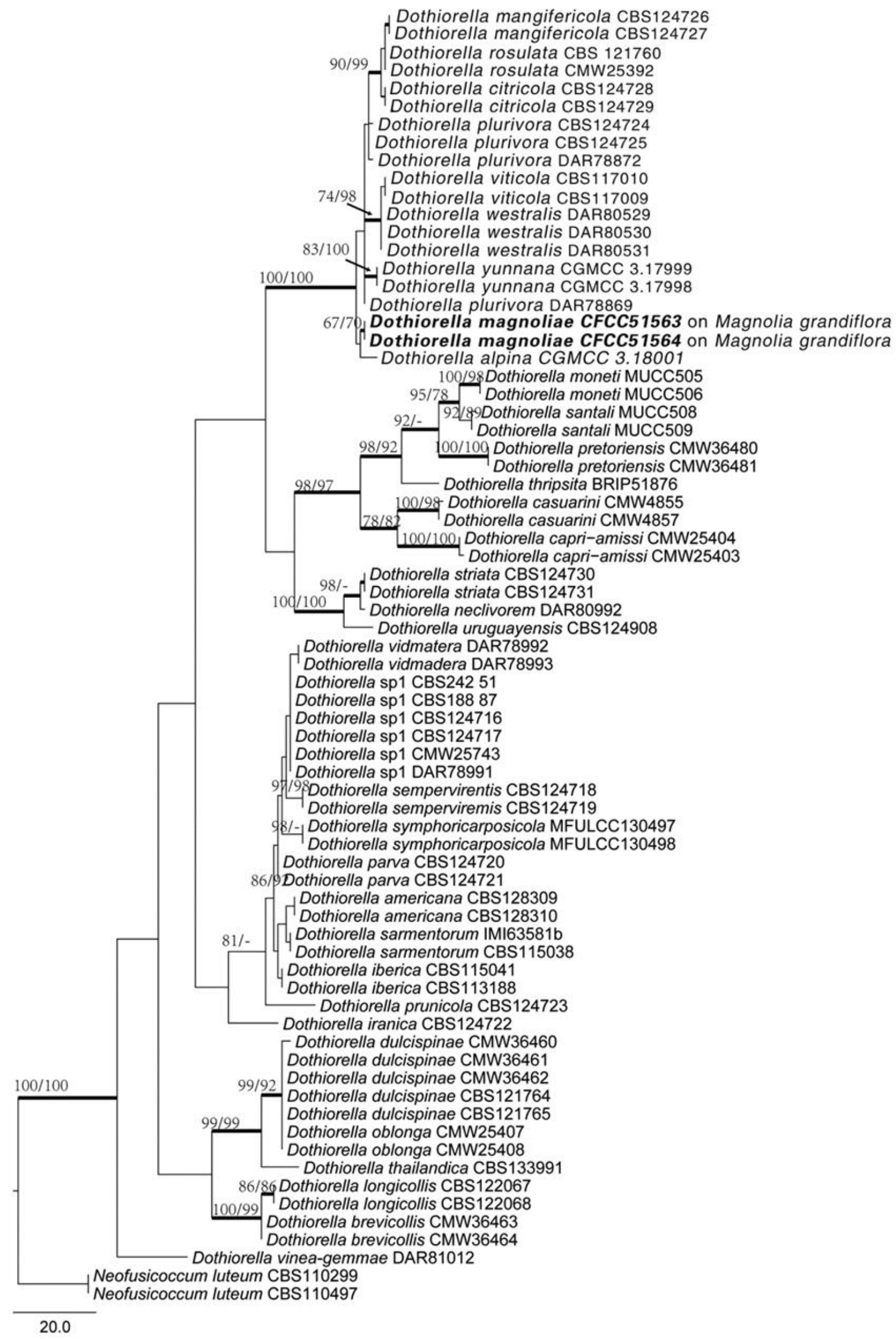

Figure 1 - Phylogram of Dothiorella based on combined ITS and TEF1- $\alpha$ genes. MP and ML bootstrap support values are shown at the first and second position (The posterior probabilities from $\mathrm{BI}$ are not shown). Scale bar $=30$ nucleotide substitutions. New species in current study are in bold. 
random trees for 1,000,000 generations, and trees were sampled every 100th generation, resulting in 10,000 total trees. The first $25 \%$ of trees were discarded as the burn-in phase of each analysis. Branches with significant Bayesian posterior probabilities (BPP) were estimated in the remaining 7,500 trees. Trees are shown using FigTree v.1.4.0 (http://tree.bio.ed.ac.uk software/figtree). Sequence alignments were deposited at TreeBase under the accession number S20262.

\section{Results}

\section{Phylogenetic analysis}

The combined ITS and tefl- $\alpha$ sequences comprised 70 ingroup strains corresponding to 35 species of Dothiorella, including two strains from this study are recognized as new species. Sequence alignment contained 677 characters, 460 for the ITS region, 217 for $t e f 1-\alpha$ gene. 677 characters were included in the final dataset, of which 497 characters were constant, 20 variable characters were parsimony-uninformative, and 160 were parsimony informative. The heuristic search generated one parsimonious tree $(\mathrm{TL}=400, \mathrm{CI}=0.623, \mathrm{RI}=0.915, \mathrm{RC}=0.570)$ as shown in Fig. 1 . Strains $\mathrm{CFCC}$ 51563 and CFCC 51564 formed a well-supported clade (MP/ML/BI = 67/70/0.91) representing a new phylogenetic species.

\section{Taxonomy}

Dothiorella magnoliae C.M. Tian, C.J. You sp. nov.

Fig. 2

MycoBank 821470; Facesoffungi number: FoF 03374 species.

Etymology - magnoliae, referring to Magnolia grandiflora, the only host known for this

Conidiogenesis - Conidiomata pycnidial, abundant, superficial, or semi-immersed, separate or aggregated into botryose cluster. Conidiogenesis holoblastic, with hyaline and cylindrical conidiogenous cells giving rise to periclinal thickenings. Conidia, initially hyaline, thin-walled, nonseptate, becoming thick-walled, brown, 1-septate prior to release from the conidiogenous cells, always deeply constricted at septum, externally smooth, internally finely verruculose, rounded at both ends, (16.00-) 20.63-22.50 (-31.35) $\times(8.14-)$ 10.87-12.03(-15.55) (av. of 50 conidia $=21.56$ $\times 11.45 \mu \mathrm{m})$, and an average length to width ratio of 1.88 .

Cultural characteristics - on PDA colonies flat and filamentous, initially leaden grey in the centre, becoming smoke grey at the margin, with white appressed mycelia radiating outwards, forming smoke-grey to olivaceous-dark at the surface and brown-dark at the reverse after 7-10 days. Colonies extending to $c a .66 \mathrm{~mm}$ diam after two weeks in the dark at room temperature.

Known distribution - Southwestern China.

Material examined - CHINA, Sichuan Province: Daofu, 2959'36"N, 10153'46"E, 3183 m asl, on twigs and branches of Magnolia grandiflora, coll. C.J. You, 10 June 2015 (BJFC-S2323, holotype), ex-type culture, CFCC 51563; Daofu, 2959'36"N, 101 ${ }^{\circ} 53^{\prime} 46^{\prime \prime} \mathrm{E}, 3183 \mathrm{~m}$ asl, on twigs and branches of Magnolia grandiflora, coll. C.J. You, 10 June 2015 (BJFC-S2324, paratype), ex-paratype culture, CFCC 51564.

Notes - Dothiorella magnoliae differs from other species of Dothiorella in having 1-septate conidia deeply constricted at the septum (Fig. 1) (Table 2). Morphologically, D. magnoliae resembles D. westralis (W. M. Pitt et al.) Tao Yang \& Crous (mean L/W: 1.9), but differs from this species in its larger conidia with rounded apex and base. The conidial size of D. magnoliae is comparable with those of D. plurivora (Abdollahz. et al.) Tao Yang \& Crous (Table 2), but they differ in conidial shapes in that most conidia of $D$. plurivora have a truncate base, while those of $D$. magnoliae are unique with rounded ends (Abdollahzadeh et al. 2014, Yang et al. 2017). 

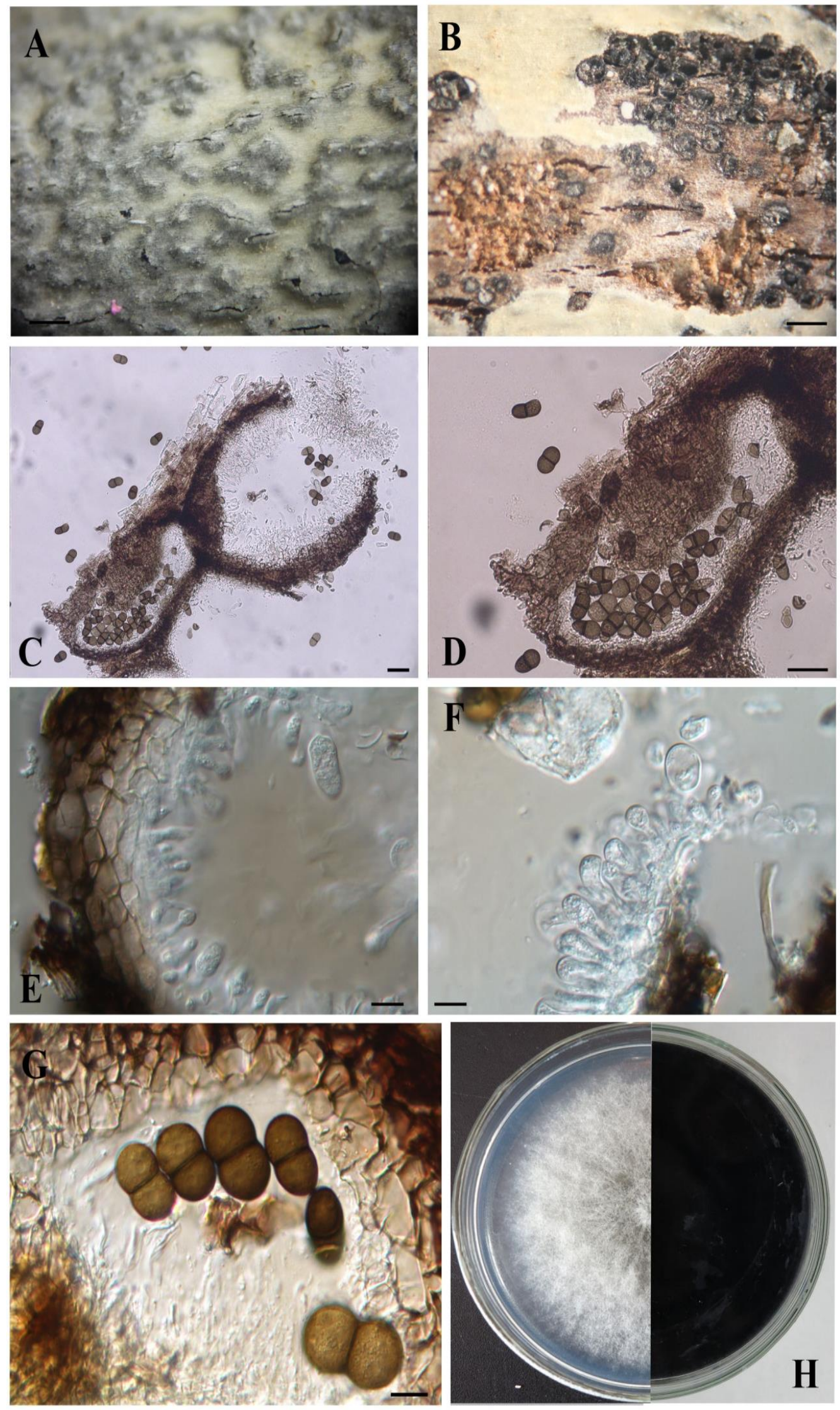

Figure 2 - Dothiorella magnoliae (Holotype CFCC 51563). A-B Black conidiomata on the host surface. C-D Vertical section of conidioma. E Section of peridium. F Conidiogenous cells and developing conidia. G Mature brown 1-septate conidia. H Culture on PDA (seven and 28 day-old colonies). Scale bars: $A=2 \mathrm{~mm}, \mathrm{~B}=2000 \mu \mathrm{m}, \mathrm{C}, \mathrm{D},=20 \mu \mathrm{m}, \mathrm{E}, \mathrm{F}, \mathrm{G}=10 \mu \mathrm{m}$. 
Table 2 Conidial dimensions and L/W ratios of selected Dothiorella species

\begin{tabular}{lcccl}
\hline & & Conidia & & References \\
Species & Dimensions $(\mu \mathrm{m})$ & Mean $(\mu \mathrm{m})$ & L/W ratio & \\
\hline D. citricola & $24-27 \times 10-12$ & $25.8 \times 12.2$ & 2.1 & Abdollahzadeh et al. (2014) \\
D. mangifericola & $17-22 \times 8-10$ & $19 \times 9$ & 2.1 & Abdollahzadeh et al. (2014) \\
D. plurivora & $20-25 \times 10-13$ & $22.5 \times 11$ & 2.1 & Abdollahzadeh et al. (2014) \\
D. viticola & $20.2-20 \times 9.2-9.4$ & $20.4 \times 9.3$ & 2.2 & Luque et al. (2005) \\
D. westralis & $18.8-19.7 \times 9.8-10.3$ & $19.3 \times 10.1$ & 1.9 & Pitt et al. (2015) \\
D. rosulata & $21-24.2 \times 10-10.5$ & $22.6 \times 10.4$ & 2.2 & Slippers et al. (2014) \\
D alpina & $19-20.4 \times 8.4-9$ & $19.7 \times 8.7$ & 2.2 & Zhang et al. (2016) \\
D. yunnana & $19.6-21 \times 8.6-9.2$ & $20.3 \times 8.9$ & 2.3 & Zhang et al. (2016) \\
D. magnoliae & $20.6-22.5 \times 10.9-12.0$ & $21.56 \times 11.45$ & 1.9 & This study \\
\hline
\end{tabular}

\section{Discussion}

In the present study, the subclade of the new species D. magnoliae nested in the Dothiorella clade and formed a sister group to other species of Dothiorella. Morphologically, the deeply constricted conidia of $D$. magnoliae can be readily distinguished from all other reported species of Dothiorella, and may serve as a diagnostic character. The molecular data also indicated its uniqueness among all know species.

The taxonomic status of Dothiorella and its closely related genus Spencermartinsia, have been discussed by various mycologists (Phillips et al. 2008, 2013, Liu et al. 2012, Pitt et al. 2013, Abdollahzadeh et al. 2014, Li et al. 2014, Pitt et al. 2015, Yang et al. 2017). Yang et al. (2017) recommended that the two genera should be reduced to a single genus Dothiorella. Six described species, S. mangiferae, S. rosulata, S. citricola, S. plurivora, S. viticola, and S. westrale have been transferred to Dothiorella. Two new species to Spencermartinsia, i.e. S. alpina and S. yunnana from Yunnan province in China, newly reported by Zhang et al. (2016) should be transferred to Dothiorella. Our study including representatives of all Dothiorella and 8 Spencermartinsia species, also revealed that Spencemartinisia is paraphyletic and the distinction between the two genera was not completely resolved (Phillips et al. 2013, Abdollahzadeh et al. 2014, Slippers et al. 2013, Pitt et al. 2015). The apiculate ascospores is not a reliable feature to differentiate these two genera, and only one Spencermartinsia species has been demonstrated to produce the sexual stage.

The new species differed from all other most related eight species of Dothiorella, which were treated as Spencermartinsia, on the basis of its unique conidial morphology in having 1-septate conidia with deeply constricted septum (Table 2). Phylogenetically, D. magnoliae was closely related to $D$. alpina, but conidia of $D$. magnoliae differed from it, being significantly longer and broader (mean L/W: 1.9), and rounder at both ends than D. alpine. Furthermore, conidia of D. magnoliae were of similar size to $D$. plurivora, but $D$. magnoliae was unique phylogenetically.

In China, only one pathogen, Pleomassaria magnoliae Shear was reported to cause canker or dieback on Magnolia denudata (Tai 1979), D. magnoliae is described for the first time, which is associated with dieback of Magnolia grandiflora from China on Magnolia. Although pathogenicity of the species described in this study has not been determined, the pathogenicity, host specificity and geographic distribution of the characterized species remain unknown and should be considered in future studies.

\section{Acknowledgements}

This research has been supported by The Fundamental Research Funds for the Central Universities, China (No. BLX2012032), and National Natural Science Foundation of China (No. 31300540). We are grateful to Chungen Piao and Minwei Guo (China Forestry Culture Collection Center (CFCC), Chinese Academy of Forestry, Beijing) for technical support in strain preservation. 


\section{References}

Abdollahzadeh J, Javadi A, Zare R, Phillips AJL. 2014 - A phylogenetic study of Dothiorella and Spencermartinsia species associated with woody plants in Iran, New Zealand, Portugal and Spain. Persoonia 32, 1-12.

Carbone I, Kohn LM. 1999 - A method for designing primer sets for speciation studies in filamentous ascomycetes. Mycologia 91, 553-556.

Dissanayake AJ, Camporesi E, Hyde KD, Phillips AJL et al. 2016a-Dothiorella species associated with woody hosts in Italy. Mycosphere 7, 51-63.

Dissanayake AJ, Phillips AJL, Li XH, Hyde KD. 2016b - Botryosphaeriaceae: Current status of genera and species. Mycosphere 7, 1001-1073.

Doilom M, Dissanayake AJ, Wanasinghe AN, Boonmee S et al. 2017 - Microfungi on Tectona grandis (teak) in northern Thailand. Fungal Divers 82, 107-182.

Hillis DM, Bull JJ. 1993 - An empirical test of bootstrapping as a method for assessing confidence in phylogenetic analysis. Systematic Biology 42, 182-192.

Katoh K, Standley DM. 2013 - MAFFT multiple sequence alignment software version 7: improvements in performance and usability. Molecular Biology \& Evolution 30, 772-780.

Li W, Liu J, Bhat DJ, Camporesi E, Xu J, Hyde KD. 2014 - Introducing the novel species, Dothiorella symphoricarposicola, from snowberry in Italy. Cryptogamie Mycologie 35, 257 270.

Liu JK, Phookamsak R, Doilom M, Wikee S et al. 2012 - Towards a natural classification of Botryosphaeriales. Fungal Divers 57, 149-210.

Luque J, Martos S, Phillips AJL. 2005 - Botryosphaeria viticola sp. nov. on grapevines: a new species with a Dothiorella anamorph. Mycologia 97, 1111-1121.

Nylander JAA. 2004 - MrModeltest v. 2. Program distributed by the author. Evolutionary Biology Centre, Uppsala University.

Phillips A, Alves A, Correia A, Luque J. 2005 - Two new species of Botryosphaeria with brown, 1septate ascospores and Dothiorella anamorphs. Mycologia 97, 513-529.

Phillips AJL, Alves A, Pennycook SR, Johnston PR et al. 2008 - Resolving the phylogenetic and taxonomic status of dark-spored teleomorph genera in the Botryosphaeriaceae. Persoonia 21, $29-55$.

Phillips AJL, Alves A, Abdollahzadeh J, Slippers B et al. 2013 - The Botryosphaeriaceae: genera and species known from culture. Studies in Mycology 76, 51-167.

Pitt WM, Huang R, Steel CC, Savocchia S. 2010 - Identification, distribution and current taxonomy of Botryosphaeriaceae species associated with grapevine decline in New South Wales and South Australia. Australian Journal of Grape Wine Research 16, 258-271.

Pitt WM, Úrbez-Torres JR, Trouillas FP. 2013 - Dothiorella vidmadera, a novel species from grapevines in Australia and notes on Spencermartinsia. Fungal Diversity 61, 209-219.

Pitt WM, Úrbez-Torres JR \& Trouillas FP. 2015 - Dothiorella and Spencermartinsia, new species and records from grapevines in Australia. Australasian Plant Pathology 44, 43-56.

Rannala B, Yang Z. 1996 - Probability distribution of molecular evolutionary trees: a new method of phylogenetic inference. Journal of Molecular Evolution 43, 304-311.

Ronquist F, Huelsenbeck JP, van der Mark P. 2005 - MrBayes 3.1 Manual.

Slippers BJ, Roux MJ, Wingfield MJ, van der Walt FJJ et al. 2014 - Confronting the constraints of morphological taxonomy in the Botryosphaeriales. Persoonia 33, 155-168.

Swofford DL, Waddell PJ, Huelsenbeck JP, Foster PG et al. 2001 - Bias in phylogenetic estimation and its relevance to the choice between parsimony and likelihood methods. Systematic Biology 50, 525-539.

Tai FL. 1979 - Sylloge Fungorum Sinicorum. Beijing, China.

White TJ, Bruns T, Lee S, Taylor J. 1990 - Amplification and direct sequencing of fungal ribosomal RNA genes for phylogenetics. In: Innis MA, Gelfand DH, Sninsky JJ, White TJ (eds), PCR Protocols: a guide to methods and applications. Academic Press, San Diego, U.S.A, pp 315322. 
Wijayawardene NN, Hyde KD, Wanasinghe DN, Papizadeh M et al. 2016 - Taxonomy and phylogeny of dematiaceous coelomycetes. Fungal Divers 77, 1-316.

Yang T, Groenewald JZ, Cheewangkoon R, Jami F et al. 2017 - Families, genera and species of Botryosphaeriales. Fungal Biology 121, 322-346.

Zhang M, He W, Wu JR, Zhang Y. 2016 - Two new species of Spencermartinsia (Botryosphaeriaceae, Botryosphaeriales) from China. Mycosphere 7, 942-949. 